\title{
LABOR STANDARDS AND ECONOMIC INTEGRATION IN THE EUROPEAN UNION: AN EMPIRICAL ANALYSIS
}

\author{
VIVEK H. DEHEJIA \\ YIAGADEESEN SAMY
}

CESIFO WORKING PAPER NO. 1746

CATEgory 3: Social Protection

JUNE 2006

Presented at CESifo AREA Conference on

EMPLOYMENT \& SOCIAL PROTECTION, MAY 2006

An electronic version of the paper may be downloaded

- from the SSRN website:

- from the RePEc website:

- from the CESifo website:

www.SSRN.com

www.RePEc.org

www.CESifo-group.de 


\title{
LABOR STANDARDS AND ECONOMIC INTEGRATION IN THE EUROPEAN UNION: AN EMPIRICAL ANALYSIS
}

\begin{abstract}
This study is motivated by frequent calls to harmonize labor standards across countries, which result from the fear that economic integration (and the accompanying liberalization of trade flows) will lead to an erosion of working conditions, as countries deliberately try to reduce labor standards in order to maintain competitiveness. We examine the linkages between labor standards and economic integration in the European Union (EU) and, in particular, investigate the following questions. First, whether the conventional wisdom that labor standards are important determinants of trade performance holds, and second whether there has been a "race to the bottom" of standards across countries with deeper integration. We follow a neoclassical factor-proportions framework to conduct our empirical investigation, and unlike previous studies, which rely mostly on cross-sectional data, we use a fully-fledged panel data set to explore the relationship between labor standards and export performance. Our estimates based on data for the period 1980-2001 for EU-15 countries provides mixed evidence regarding the conventional wisdom, and we find that trade performance is largely based on factor endowments. We also find mixed evidence for " $\sigma$-convergence" in labor standards.
\end{abstract}

JEL Code: J8.

Keywords: economic integration, labor standards, comparative advantage, $\sigma$-convergence.

\author{
Vivek H. Dehejia \\ Department of Economics \\ Carleton University \\ 1125 Colonel By Drive \\ Ottawa ON K1S $5 B 6$ \\ Canada \\ vdehejia@ccs.carleton.ca
}

\author{
Yiagadeesen Samy \\ The Norman Paterson School of \\ International Affairs \\ Carleton University \\ 1125 Colonel By Drive \\ Ottawa ON K1S 5B6 \\ Canada \\ ysamy@connect.carleton.ca
}

June 5, 2006

Earlier versions of this paper were presented at the Centre for European Studies, Carleton University, Ottawa, Canada, October 2005, and at the CESifo Area Conference on "Employment and Social Protection”, Munich, Germany, 26/27 May 2006. We would like to thank the CESifo discussant, Robert Jäckle, as well as conference participants for their helpful comments and suggestions. The responsibility for errors and opinions is our own. 


\section{Labor Standards and Economic Integration in the European Union: An Empirical Analysis}

\section{Introduction}

This paper examines the conventional wisdom that globalization will undermine the ability of national governments to set economic and social policy. More precisely, it considers the linkages between economic integration ${ }^{1}$ and labor standards in the European Union over the period 1980-2001. Questions of trade and labor standards are not new and have been widely analyzed, both theoretically and empirically, especially in a North-South context. The question remains whether as economies become increasingly integrated, ceteris paribus, countries with lower labor standards obtain an unfair advantage in trade due to lower labor costs. Much of the literature argues that labor standards matter and that countries that have relatively low labor standards obtain "unfair" gains from trade. It should therefore not come as a surprise that countries such as the United States and France have been pushing for the inclusion of labor standards at the WTO level for a number of years.

Developing countries view this argument as disguised protectionism and as being equally unfair as it will erode their competitiveness, which is largely based on labor costs. While this issue has been extensively analyzed in a North-South framework, its importance has been overlooked among developed nations that are characterized by similar political systems, and that are part of regional trade agreements. In a report released by the World Commission on the Social Dimension of Globalization of the International Labor Organization (ILO) in February 2004 entitled "A Fair Globalization: Creating Opportunities for All", it is argued that stronger action is required to ensure respect for core labor standards in global production systems. No attention, however, is given to this debate

\footnotetext{
${ }^{1}$ The term economic integration is preferred to globalization as it is more precise and helps us to consider trade flows specifically.
} 
within the context of existing regional trade agreements among (mostly) developed countries.

This paper tries to fill some of the gap in this literature by considering the linkages that exist between labor standards and economic integration in the European Union. The European Union (EU) represents, in our view, the ideal candidate for such an analysis, and for the following reasons. From a regional economic agreement among six neighboring states in the 1950s, the EU has evolved into a supranational organization of twenty-five countries across the European continent. It currently stands as the largest trading area in the world, and European integration has proceeded the furthest, especially with the creation of the Single European Market and the Economic and Monetary Union (EMU). Labor, capital, goods and services flow freely across borders, and most members of the EU share a common currency, the EURO. Nations and societies with different norms and rules that govern their individual labor markets have thus been brought into closer and more frequent contact with one another as a result of integration. Even though labor standards and labor market regulations are a purely domestic matter, and presumably shaped by domestic interest groups, voters and national governments, one could argue that policies in one nation are now more likely to have welfare redistribution effects and repercussions for levels of labor protection in other nations. The recent addition of 10 new members to the EU in May 2004 which are at different levels of economic development, and the possibility of further enlargement in 2007 (which includes Turkey) poses new challenges that also need to be addressed. It is noteworthy that freedom of movement for labor has not generally been granted to the 10 new members, this being phased in gradually in the original 15 members vis-à-vis the newcomers. Fears of pressure on wages and erosion of labor standards wrought by the "Polish plumber" played an important role in the recent, indecisive German federal 
election (September, 2005), and also animated opposition to the initiation of accession talks with Turkey (October, 2005). These concerns are evidently of political import and worthy of further investigation.

Furthermore, and on a more pragmatic note, the EU has been in existence for enough years: the availability of reliable data, both cross-section and time series, makes empirical analysis possible. Regarding labor standards themselves, the EU has traditionally tried to ensure a "decent" working environment throughout member countries, by setting some common minimum rules on working conditions, and promoting a safe and healthy work environment, but leaving some room for preservation of policy independence and diversity (Gitterman 2003).

In this paper, we follow the OECD (1996) and define labor standards as norms, rules and conventions that govern working conditions and industrial relations. Such a definition captures all the institutional elements of labor markets such as minimum wages, occupational health and safety standards, number of hours worked, rates of occupational injuries, and unionization rates. ${ }^{2}$ One would presumably expect labor standards to be a driven by both a country's level of development and its respect for international conventions defined by the ILO that it has ratified. Ultimately, the choice of a particular standard is a domestic policy choice, which suggests to us as economists that diversity of standards should be the norm rather than the exception. The theory of commercial policy proposes that gains from trade arise from diversity, and that an enforced harmonization or "straitjacketing" of countries to a particular standard, whether higher or lower than would have been chosen

\footnotetext{
2 The literature on labor standards often refers to core labor standards, which are represented by eight ILO conventions defining four fundamental rights at work, and they are supported internationally, which implies that they apply regardless of a country's level of economic development.
} 
otherwise, will generally be harmful to welfare. ${ }^{3}$ Hence, the argument that countries should restrict access to markets when there are suspicions that products are being made under poor working conditions is one that needs to be dealt with caution.

This paper thus seeks to answer two questions related to the issue of economic integration and labor standards. First, the paper tries to ascertain empirically whether countries with high labor standards experience a loss of competitiveness measured by export performance; in other words, to what extent are trade flows determined by labor standards when one controls for natural determinants of comparative advantage. The conventional wisdom argues that countries with lower labor standards should enjoy a better export performance; this should be even more felt in the case of labor-intensive production and exports. Second, the paper examines the "race to the bottom" argument that low labor standards provide an unfair source of comparative advantage, and that increasing imports from low-standards countries will have an adverse impact on wages and working conditions in high-standards countries. With the free movement of capital, the argument runs, new capital investment will flow to regions where labor standards are lower, and wages cheaper, therefore placing downward pressure on domestic standards as erstwhile high-standard countries ratchet standards downward in order to remain competitive. This argument, however, is a theoretical possibility, not an empirical necessity, and in need of further investigation. In so doing, we will address the issue of convergence or harmonization of standards across countries as a result of increased economic integration.

The rest of the paper proceeds as follows. Section 2 briefly surveys the history of labor standards in the European Union. Section 3 discusses existing theoretical and

\footnotetext{
${ }^{3}$ Brown, Deardorff, and Stern (1996) furnish an argument that purports to show that harmonization of standards may in certain circumstances be welfare-improving in a standard model, but Dehejia (1998)
} 
empirical work. Section 4 presents the models tested and empirical evidence related to the two questions outlined in the previous paragraph. Section 5 concludes.

\section{Labor Standards in the European Union - A Brief History ${ }^{4}$}

International labor standards as we know them today originate from the aftermath of the Industrial Revolution in Great Britain at the beginning of the $19^{\text {th }}$ century. Attempts were made to offset the negative externalities associated with industrialization in order to protect members of the working class and these were generally met by opposition from employers even though there were benefits (arguably) accruing to the latter. ${ }^{5}$ Standards pertaining to minimum age and maximum hours worked were thus applied to women and children as they were believed to be unable to decide for themselves, had very few (if any) political rights and were typically not members of bargaining units. Historians of labor standards refer to the English Factory Act of 1802 introduced by Sir Robert Peel as the starting point, which set limits on hours of work and asked that education and religious instruction be provided to apprentices. Subsequent legislation in the $19^{\text {th }}$ century expanded coverage and requirements.

Over the course of the $19^{\text {th }}$ century, most European nations had standards in place for factory labor, and at least initially, they established their own standards independently of one another. Colonies were, however, excluded from these regulations.

Parallel to this evolution of national labor standards, there were some attempts to establish international labor standards as well. As discussed in Engerman (2003), there were concerns about the costs that a country would have to face if it unilaterally set standards for itself and the resulting loss in competitiveness; some also argued in favor of international

demonstrates that this result arises from second-best considerations (adjusting the stringency of standards serves as a proxy for a tariff), and that the first-best optimum is characterized by diversity of standards.

${ }^{4}$ See Engerman (2003) for a more comprehensive treatment. 
standards on moral grounds to improve world welfare. Conferences and bilateral agreements in the second part of the $19^{\text {th }}$ century did not achieve much in terms of setting international standards despite calls for the latter, probably due to a lack of political will. Even though bilateral and multilateral agreements on labor issues were signed, enforcement of standards was very weak and essentially ineffective. The creation of the ILO in 1919 under the League of Nations marks the real beginning of international labor standards. Today, the ILO as a specialized agency of the United Nations, and with more than 170 members (including all countries of the EU), promotes social justice and international labor standards worldwide. It formulates international labor standards in the form of conventions and recommendations, and provides technical assistance in a number of areas such as work, employment, social security, social policy and related human rights. The ILO Declaration of fundamental principles and rights at work, drafted and adopted in 1998, requires all members to observe core labor standards which cover rights pertaining to elimination of forced labor, abolition of child labor, non-discrimination in employment and right to freedom of association and collective bargaining. These rights are represented by eight ILO Conventions, and all the members of the EU have ratified them.

Since its creation, the EU has always striven to ensure a decent working environment in member countries, establishing minimum standards for working conditions. Countries that are highly regulated cannot impose their standards on those that are not; instead, any change in regulation has to come about as a result of interaction among domestic interest groups, member states, EU associations, and within the parameters of existing rules. Under the Treaty of Rome of 1958, the six founding members (Belgium, Netherlands,

\footnotetext{
${ }^{5}$ We have in mind "efficiency wage" type arguments, in which higher standards (or wages) lead to greater productivity (and hence higher ex-ante profits) for firms, as, for instance, better off workers are less likely to shirk or be absent due to malnutrition or illness.
} 
Luxembourg, West Germany, France, Italy) agreed to raise employment conditions in member states, and changes required a unanimous decision by the Council of Ministers. As membership increased (Denmark, Ireland and UK in 1973; Greece in 1981; Spain and Portugal in 1986), more pressures for harmonization resulted but most of them failed to result in a change in the policy framework. Members committed themselves to a social agreement in 1972, and the Social Action Program was launched in 1974. Several directives proposed by the European Commission in the 1980s and early 1990s were not approved by the Council and only a few are legally binding on member countries. Those that were approved include health and safety requirements in the 1980s and a directive on working time arrangements in 1993.

In the 1989 Community Charter of Fundamental Social Rights (the Social Charter), member states of the EU committed to some fundamental rights such as freedom to organize and bargain collectively, and health and safety in the workplace. However, since changes required unanimous support, the job of the Commission was made extremely difficult. The Charter, which was mainly a political declaration, had no legal force and was not binding upon signatory countries. With the Maastricht Treaty and its Protocol on Social Policy in 1992, the EU is now able to intervene, legislate and make changes in worker health and safety regulations as long as a qualified majority of member states are in agreement. Since the Maastricht Treaty retained the provisions in previous treaties, members were still in control of their own right to pay, right to association, and right to strike or impose lockouts. The Amsterdam Treaty, which came into force in 1999, now allows qualified majority voting in some additional issues (but the rights to association, strike and lockouts are still excluded). Even though the dominant view in the 1990s was that integration could only go forward 
with harmonization of labor and good markets regulation, some countries (the UK and Portugal namely) called for more labor market flexibility.

At the 2000 European Council meeting in Nice, a European Union Charter of Fundamental Rights was signed, but as it stands, these rights are principles rather than binding rights. In short, one can argue that EU member states do not harmonize labor standards, even though they seem to agree on the lowest common denominator of standards. Even though the EU sets minimum standards, countries have retained most of their policy autonomy and diversity. EU policy pertaining to labor standards remains noninterventionist, despite the fact that the European Commission has more powers to intervene. Section 4 of the paper will examine the empirical evidence regarding this issue. Before conducting our empirical analysis, we will review some of the important existing work in this area in the next section.

\section{Literature Review: Theoretical and Empirical}

Theoretical work linking international trade with labor standards is relatively scarce. The classic early studies, for instance by Johnson (1969) and Brecher (1974a and 1974b), considered minimum wages and their welfare implications but did not consider other internationally accepted labor standards such as the number of hours worked, the freedom from forced labor or unionization. On the other hand, Alam (1992), in an unpublished doctoral dissertation, was one of the first to provide a more general framework for the economic analysis of the impact of labor standards, at constant goods prices, on a country's comparative advantage within the framework of a two-country, two-commodity, two-factor model. 
Brown et al. (1996) focused on the welfare and other effects of standards and whether it is in a country's interest to implement common international standards. They use general equilibrium analysis by considering different variants of the standard two-good twofactor Heckscher-Ohlin-Samuelson model in order to analyse the effects of standards on the terms of trade. The different models in Brown et al. show that the effects of labor standards are dependent on the technology of production of goods and standards, and also on whether the standards are endogenous. An important result in their paper is that harmonization of standards is not beneficial to high-standard (developed) countries. Economic welfare is maximized when countries correct their domestic labor market failures, and since market failures are likely to be different across countries and cannot be corrected by similar measures, the case for international harmonization of labor standards is rather weak. Furthermore, harmonization of labor standards (for example eliminating child labor) can in fact unintentionally hurt the people that it is supposed to protect. Some of these results are anticipated as well in unpublished work by Dehejia and Garbo (1994). Indeed, T. N. Srinivasan (1995) has rigorously shown that diversity of standards is consistent with the case for free trade. His analysis shows that international income transfers or domestic tax/subsidies can help attain minimum standards (even in the presence of market failures), and that the use of trade policies can on the contrary prevent the attainment of better standards. This is consonant with the classic Bhagwati-Ramaswami-Johnson "targeting" theorem in the theory of commercial policy (see Bhagwati and Ramaswami (1963) and Johnson (1965)).

Dehejia and Samy (2004) have more recently built on the Brown et. al. (1996) analysis to investigate formally the links between labor standards and comparative advantage. Their results indicate that countries can benefit or be hurt by a labor standard depending, first, on 
whether the latter is imposed in their import or export sector, and, second, on the relative factor intensity of the traded goods sector. More importantly, their model predicts that in the absence of coordination, countries will tend to underprovide or overprovide a standard, thus failing to reach a world optimum in the presence of trade. However, it does not generally follow that an enforced harmonization of standards will be welfare-improving for the world; indeed, the contrary result is more likely. The overall conclusion of the theoretical analyses outlined above is that diversity of labor standards between countries should be expected, and that such diversity need not be regarded as being unfair as long as labor standards are a result of an efficient allocation of resources.

Since the publication of the OECD (1996) study of Trade, Employment and Labor Standards, a number of studies have examined the empirical relationship between trade and labor standards, namely whether countries with lower labor standards will tend to gain a comparative advantage in trade. The OECD (1996) study itself examined export performance for developed and developing countries versus freedom of association and collective bargaining rights as proxies for labor standards. Based mostly on "eyeballing" scatterplots, but without a rigorous econometric analysis, it found no evidence that lowstandard countries enjoy a better export performance than high-standard countries.

Mah (1997) analyzed the relationship between core labor standards and the export performance of developing countries in a more rigorous fashion. More specifically, he considered the ratification of ILO conventions related to core labor standards for forty-five developing countries as an independent variable to analyze their export performance for 1993. Unlike the OECD (1996) study, whose results, as mentioned, were based on looking at scatterplots, his regression results showed that ratification of the conventions related to freedom of association, collective bargaining, and non-discrimination lead to a deterioration 
of export performance. Similar results are obtained even when a capital cost element is added as an additional explanatory variable. Mah's results thus contradict the OECD findings that there is no relationship between export performance and the level of labor standards. His results are problematic as only conventions ratified are used as indicators for labor standards, ${ }^{6}$ and no attempt is made to control for other factors that might influence competitiveness, which vitiates his econometric methodology.

Subsequent studies (for example Rodrik (1996), Flanagan (2002), Dehejia and Samy (2004)) based on large sample statistical analysis found no (or very weak) evidence that low labor standards have an impact on trade. Instead, trade patterns are determined by the natural determinants of comparative advantage in the form of factor endowments (which confirms the predictions of standard trade models). The Flanagan (2004) study is innovative in that it uses panel data, but, again, the validity of the results can be questioned as ILO conventions are used as proxies for labor standards. The Rodrik (1996) and Dehejia and Samy (2004) studies are more compelling since these authors use a variety of better indicators for labor standards. In addition to ILO conventions ratified, they also consider other indicators such as the number of hours worked, rates of occupational injuries, unionization rates and estimates of child labor. Their analysis is comprehensive as it covers cross-sectional data for the manufacturing and labor-intensive sectors for many developing and developed countries, and they are able to control for the natural determinants of comparative advantage.

Dehejia and Samy (2004) also find that labor standards seem to play a more important role for developing countries' trade performance, which is not surprising, given that these countries are labor abundant and specialize mostly in labor-intensive goods. In

\footnotetext{
${ }^{6}$ It is not at all clear that countries which ratify ILO conventions are in fact implementing and enforcing them.
} 
another interesting study, Rodriguez and Samy (2003) using time series data and sophisticated econometric techniques have examined the effects of labor standards on US export performance. Because of the existence of structural breaks in the data, they are able to examine the influence of labor standards under different regimes, and the evolution of this influence over time. They obtain very weak evidence that low standards help boost export competitiveness. ${ }^{7}$ Rodriguez and Samy (2003) and Dehejia and Samy (2004) are to our knowledge the only studies that have made use of time series data for developed countries (Canada and the US) that are members of regional trade agreements.

Another study of interest is Van Beers (1998), who considers the relationship between labor standards and trade flows of OECD countries using a labor standard indicator based on actual labor regulations. The indicator is a synthetic index constructed by the OECD and which takes into account the enforcement of various government regulations such as working time, employment contracts, minimum wages and worker's rights. Van Beers extends a gravity model, which considers bilateral trade flows, with variables that represent the strictness of labor regulations and tests the hypothesis whether labor standards have a detrimental effect on exports due to a fall in competitiveness. His results based on 1992 data do not show any significant impact of labor standards stringency on exports of labor-intensive commodities. However, when a distinction is made in terms of skill-intensities, both the exports of labor-intensive and capital-intensive commodities, which are produced with relatively high-skilled labor, deteriorate with an increase in the strictness of labor standards. Van Beers attributes the latter result to the relatively inelastic demand for high-skilled labor which implies that labor costs rise more than in the case of

\footnotetext{
7 There are also a number of studies that have examined the relationship between labor standards and foreign direct investment (FDI) to verify allegations that countries with lower labor standards are able to attract more
} 
low-skilled labor intensive commodities. No attempt, however, is made to check the robustness of the results for subsequent years, and to use different indicators of labor standards for sensitivity analysis.

In another study, Krueger (2000) has examined the impact that the EU will have on the labor compact, ${ }^{8}$ focusing in particular on the race to the bottom hypothesis that countries will have to lower their standards to maintain a competitive advantage in trade. Overall, his results indicate that even though integration will cause some downward pressure on labor market protections (that is, looser regulation), this pressure will be modest, and European nations will continue to maintain distinct labor practices as long as they are willing to bear the costs of these practices. Krueger gives several reasons why this should not come as a surprise. First, certain aspects of the labor compact can improve economic efficiency; second, imperfect mobility of factor inputs and goods and services will tend to diminish the pressure placed on uncompetitive labor practices; and third, for political economy reasons, labor legislation within each country is a reflection of what the majority of the public wants.

Krueger considers labor mobility among EU countries and argues that it has not increased despite the removal of restrictions on labor mobility within the EU. Furthermore, considering immigration over the period 1980-1996, he finds that immigration from non-EU countries has declined since 1993 even though these countries are typically characterized by lower living standards and weak social protection. Recent migration data seems to indicate that this trend has reversed in the latter patter of the 1990s, with migration from non-EU countries on the rise (see Appendix A), while migration across the EU seems to be fairly

FDI. The available empirical evidence to date indicates that this is not true and that the opposite is actually taking place (see for example, Rodrik (1996)).

${ }^{8}$ Krueger uses the term labor compact to capture the bargain among labor, capital and government, covering issues such as pay, social protection, union organization and safety standards. 
stable. In our empirical analysis, we will take a systematic look at the race to the bottom hypothesis for a number of indicators of labor standards.

\section{Description of the Data}

Using time-series-cross-section (pooled) data over the period 1980-2001 for $15 \mathrm{EU}$ countries, ${ }^{9}$ we test the proposition that labor standards have an influence on trade (export) performance. Not all of these countries were EU members at the beginning of the time period considered but they belonged to other trading arrangements such as the European Free Trade Area, and hence one can argue that there were substantial trade linkages among them. Even though European economic integration dates back to the 1950s, the period that we cover includes the Single European Act, the Social Charter and the Maastricht Treaty, which were all important milestones for the integration process. Data on manufactured exports (lex), GDP, population and size of countries are from the World Development Indicators of the World Bank. We also have data for exports of manufactured goods within the EU, leu, from the OECD trade database over the period 1988-2001, as well as data for labor intensive manufactured goods, llabint (both as percentages of GDP and in log form). Since labor costs are more important for labor intensive commodities, one would expect exports of labor intensive commodities to be relatively low in countries with relatively high labor standards. The human capital variable, Ihuman, refers to the average years of education of the working-age population as used by Bassanini and Scarpetta (2001) with missing values obtained from various issues of Education at a Glance, OECD.

All of the EU countries mentioned in our sample have ratified the eight core (fundamental) conventions on international labor standards. ILOLEX, which is a database 
of international labor standards from the ILO also provides information about the total number of conventions ratified by each country and the dates of ratification. Table 1 below summarizes the current situation. There is quite a range in the data with Spain having ratified the largest number and Austria the lowest (out of a possible 185 Conventions). Unlike previous studies, however, we do not use the above as an indication of existing standards since it is not possible to tell whether these conventions are in fact being enforced. Instead, we use several indicators for labor standards, which are described below.

\section{Table 1: Total ILO Conventions Ratified by EU-15 Countries}

\begin{tabular}{lc}
\hline Country & $\begin{array}{c}\text { Number of ILO } \\
\text { Conventions Ratified }\end{array}$ \\
\hline \hline Austria & 53 \\
Belgium & 96 \\
Denmark & 70 \\
Finland & 100 \\
France & 124 \\
Germany & 88 \\
Greece & 71 \\
Ireland & 73 \\
Italy & 111 \\
Luxembourg & 76 \\
Netherlands & 104 \\
Portugal & 77 \\
Spain & 129 \\
Sweden & 93 \\
United Kingdom & 86 \\
\hline \hline
\end{tabular}

Source: ILOLEX Database, ILO.

We consider total public social expenditure as a percentage of GDP, lsoc, from the OECD Social Expenditure Database as one of the indicators for labor standards. In the analysis of convergence of standards, we take into account some of its subdivisions as well, namely old-age expenditure and expenditure on unemployment (all as percentages of GDP). Public social expenditure includes unemployment benefits and incapacity related benefits, which can be conceived as indicators of labor standards in a given country. All of the

\footnotetext{
9 The countries considered are: Austria, Belgium, Denmark, Finland, France, Germany, Greece, Ireland, Italy, Luxembourg, Netherlands, Portugal, Spain, Sweden and the United Kingdom.
} 
countries in our sample provide social protection such as pensions, unemployment benefits and income support schemes. We consider an overall index of labor market well-being from the Centre for the Study of Living Standards, denoted as lwell. We have data for the latter that covers the period 1980-2001 for nine countries in our sample. The index takes into account average returns from work, the aggregate accumulation of human capital, inequality in current returns from work, and insecurity in the anticipation of future returns from work. The highest level of well-being in 2001 was in Belgium and the lowest in Italy. Finland recorded the largest improvement over the period, while Denmark had the smallest.

We consider two indicators for hours worked, lhou and lhour. The first one refers to the number of actual weekly hours worked in the manufacturing sector by wage earners and salaried employees, and is obtained from the ILO database LABORSTA. The second one is an index of hours worked from the OECD derived from the average hours worked in a given country multiplied by a measure of employment for the country. It is important to note that working time arrangements are either set by law or through collective bargaining agreements in most EU member countries, and countries differ in their approach to the regulation of working time. Most countries in our sample have a statutory maximum working week of 48 hours (as set in the EU working time directive) or 40 hours. The only exception is Belgium with a maximum working week of 38 hours. Our data considers the actual hours worked as opposed to what the regulations establish.

Trade union density rates, lunion, are also considered and they are obtained from the OECD Labor Market Statistics Database, which are based on surveys or administrative data. We also have data on strikes and lockouts, lstr, for most of the countries over the period considered, which reflects the ability of workers to express their concerns. Finally, we consider occupational injuries, linj, in the manufacturing sector per thousand people 
employed or insured, which is an indicator of safety at the workplace. As one can imagine, none of these indicators are perfect but compared to ILO conventions (which are ratified but not necessarily enforced), our indicators measure actual labor regulations.

Table 2 provides summary statistics for the variables that are used in the empirical analysis. As one can see, we have more observations for lex than leu or llabint, which are the three dependent variables that we will use in the three separate sets of regressions (in tables 3-5 below) for our measure of export performance. The mean and median values are not too different for most variables, and the standard deviations are quite small in most cases.

\section{Table 2: Summary Statistics}

\begin{tabular}{lcccc}
\hline \hline Variable Name & $\begin{array}{c}\text { Number of } \\
\text { Observations }\end{array}$ & Mean & Median & $\begin{array}{c}\text { Standard } \\
\text { Deviation }\end{array}$ \\
\hline \hline lex & 311 & -0.30 & -0.25 & 0.17 \\
leu & 189 & -8.77 & -8.79 & 0.61 \\
llabint & 189 & -10.24 & -10.20 & 0.69 \\
lpop & 330 & 4.28 & 4.28 & 0.90 \\
lhuman & 294 & 2.29 & 2.33 & 0.17 \\
lwell & 198 & -0.59 & -0.57 & 0.12 \\
lsoc & 322 & 3.14 & 3.16 & 0.23 \\
lhou & 270 & 3.62 & 3.66 & 0.10 \\
lhour & 303 & 4.53 & 4.56 & 0.11 \\
lunion & 330 & 3.64 & 3.69 & 0.59 \\
linj & 163 & 1.40 & 1.44 & 0.68 \\
lstr & 259 & 4.67 & 5.02 & 1.95 \\
\hline \hline
\end{tabular}

Note: All variables are in natural logs.

\section{Empirical Analysis}

\subsection{Labor Standards and Export Performance}

As shown by Brown et al. (1996) and Dehejia and Samy (2004), theoretically, a labor standard that uses some capital and labor (and is therefore an additional cost) may alter a country's comparative advantage depending on the factor intensity of the standard and factor endowments of the country (which in turn determine whether the country is an exporter or importer of the good affected by the standard). In a Heckscher-Ohlin framework, an 
increase in the labor force of a given labor-abundant country (due for example to a reduction in the minimum age for employment - which can be conceived as a decrease in labor standards), will increase production of the goods that use labor intensively, improving the country's comparative advantage in that good..$^{10}$ This will also change the terms of trade as a result of an increase in export supply and affect the terms of trade of the country's trading partner. It is possible to construct different scenarios that will indicate the trade and welfare effects of the standard, namely whether countries gain or lose from the imposition of standards.

Empirically, therefore, it is important to determine whether labor standards can affect comparative advantage and hence trade flows as measured by export performance. As seen in section 2 of the paper, studies that have examined this question have considered developing countries mostly and the empirical evidence is far from being conclusive. Following Rodrik (1996), Mah (1997) and Dehejia and Samy (2004), we use a trade equation augmented with labor standard variables to assess the link between labor standards and trade performance. Our general specification is

$Y_{i t}=f\left(X_{i t}, L_{i t}\right)$

where $Y_{i t}$ is manufactured exports (lex) of country $i$ at time $t$ as a fraction of country $i$ s merchandise exports at time $t ;{ }^{11} X_{i t}$ refers to a vector of variables that proxy for the natural determinants of comparative advantage; and $L_{i t}$ refers to any of the proxies for labor standards outlined in the previous section. In particular, we will use the working-age population-to-land ratio (lpop) and average years of education of the working-age population

\footnotetext{
10 This is what is commonly known in the trade literature as the Rybczynski (1955) effect.

11 We also consider an alternate definition of the dependent variable which is manufactured exports to EU (leu) countries only as a fraction of GDP, calculated from bilateral trade data obtained from the OECD trade database.
} 
(Ihuman) as our X's to proxy for the labor/land ratio and human capital respectively. Both of these variables are expected to be positively related to the dependent variable.

The maximum coverage in our data spans the period 1980-2001, and the maximum number of countries in our sample is fifteen, depending on data availability. In effect we have an unbalanced panel since we do not have full observations for all countries. The functional form that we use is a log-linear version of the above general specification where all variables are measured in natural logarithms:

$\ln Y_{i t}=\beta_{o}+\beta_{1} \ln X_{i t}+\beta_{2} \ln L_{i t}+\mu_{i}+\varepsilon_{i t}$

The country fixed effect is $\mu_{i}$ and $\varepsilon_{i t}$ is the normal disturbance term. The fixed effect model is normally preferred because it takes into account time-invariant unobservable country heterogeneity, which is possibly correlated with the dependent variable. Furthermore, it is usually recommended when the number of groups (countries) is less than the number of time periods (years). However, a Hausman test was employed to compare the fixed and random effects estimates of coefficients and equation (1) estimated accordingly. One would expect, as the conventional wisdom holds, that low-standard countries will enjoy a better export performance than high-standard countries because of lower costs. In fact, as shown by Rodrik (1996), labor standards are significant determinants of labor costs when allowance is made for productivity. There is also the possibility, however, that labor standards can improve the production process, encourage workers to perform better, and improve productivity. For example, providing workers with more safety at the workplace may induce them to perform better. The overall effect on export performance may therefore not be as clear as expected, and hence we have no a priori on the $\operatorname{sign}$ of $\beta_{2}$. 
Tables 3-5 show the results when equation (2) is estimated using various indicators of labor standards. In table 3, the dependent variable is manufactured exports as a percentage of total exports (in natural logs) and the Hausman test provided strong evidence against the null hypothesis that there is no misspecification in the case of random effects. As a result, fixed effects estimates are reported with panel corrected standard errors. ${ }^{12}$

\section{Table 3: Panel Data Estimates for Equation 2 - Dependent Variable lex}

\begin{tabular}{|c|c|c|c|c|c|c|c|}
\hline $\begin{array}{l}\text { Explanatory } \\
\text { Variables }\end{array}$ & (1) & (2) & (3) & (4) & (5) & (6) & (7) \\
\hline Constant & $\begin{array}{l}-5.292^{* *} \\
(-10.077)\end{array}$ & $\begin{array}{l}-7.580^{* *} \\
(-7.574)\end{array}$ & $\begin{array}{l}-5.399 * * \\
(-10.896)\end{array}$ & $\begin{array}{l}-6.388^{* *} \\
(-12.586)\end{array}$ & $\begin{array}{c}-4.602^{* *} \\
(8.131)\end{array}$ & $\begin{array}{c}-4.632 \\
(-7.559)\end{array}$ & $\begin{array}{l}-6.039 * * \\
(-11.648)\end{array}$ \\
\hline lpop & $\begin{array}{l}1.110^{* *} \\
(7.267)\end{array}$ & $\begin{array}{l}1.585^{* *} \\
(7.032)\end{array}$ & $\begin{array}{l}1.159^{* *} \\
(8.050)\end{array}$ & $\begin{array}{l}1.124 * * \\
(7.533)\end{array}$ & $\begin{array}{c}0.975 * * \\
(6.035)\end{array}$ & $\begin{array}{c}0.922 * * \\
(4.597)\end{array}$ & $\begin{array}{l}1.346 * * \\
(9.056)\end{array}$ \\
\hline Ihuman & $\begin{array}{l}0.116^{*} \\
(1.636)\end{array}$ & $\begin{array}{c}0.130 \\
(0.982)\end{array}$ & $\begin{array}{c}0.191^{* *} \\
(2.524)\end{array}$ & $\begin{array}{c}0.086 \\
(1.249)\end{array}$ & $\begin{array}{c}0.146^{* *} \\
(2.015)\end{array}$ & $\begin{array}{c}0.318^{* *} \\
(2.897)\end{array}$ & $\begin{array}{c}0.059 \\
(0.859)\end{array}$ \\
\hline lwell & $\begin{array}{l}- \\
-\end{array}$ & $\begin{array}{c}0.007 \\
(0.064)\end{array}$ & $\begin{array}{l}- \\
-\end{array}$ & $\begin{array}{l}- \\
-\end{array}$ & $\begin{array}{l}- \\
-\end{array}$ & $\begin{array}{l}- \\
-\end{array}$ & $\begin{array}{l}- \\
-\end{array}$ \\
\hline lsoc & $\begin{array}{l}- \\
-\end{array}$ & $\begin{array}{l}- \\
-\end{array}$ & $\begin{array}{c}-0.090^{* *} \\
(-2.929)\end{array}$ & $\begin{array}{l}- \\
-\end{array}$ & $\begin{array}{l}- \\
-\end{array}$ & - & $\begin{array}{l}- \\
-\end{array}$ \\
\hline lhour & $\begin{array}{l}- \\
-\end{array}$ & $\begin{array}{l}- \\
-\end{array}$ & $\begin{array}{l}- \\
-\end{array}$ & $\begin{array}{c}0.240^{* *} \\
(3.754)\end{array}$ & - & $\begin{array}{l}- \\
-\end{array}$ & $\begin{array}{l}- \\
-\end{array}$ \\
\hline lunion & $\begin{array}{l}- \\
-\end{array}$ & $\begin{array}{l}- \\
-\end{array}$ & $\begin{array}{l}- \\
-\end{array}$ & $\begin{array}{l}- \\
-\end{array}$ & $\begin{array}{c}-0.050^{* *} \\
(-3.852)\end{array}$ & $\begin{array}{l}- \\
-\end{array}$ & $\begin{array}{l}- \\
-\end{array}$ \\
\hline linj & $\begin{array}{l}- \\
-\end{array}$ & $\begin{array}{l}- \\
-\end{array}$ & - & $\begin{array}{l}- \\
-\end{array}$ & $\begin{array}{l}- \\
-\end{array}$ & $\begin{array}{l}-0.010 \\
(-1.026)\end{array}$ & $\begin{array}{l}- \\
-\end{array}$ \\
\hline lstr & $\begin{array}{l}- \\
-\end{array}$ & $\begin{array}{l}- \\
-\end{array}$ & $\begin{array}{l}- \\
-\end{array}$ & $\begin{array}{l}- \\
-\end{array}$ & $\begin{array}{l}- \\
-\end{array}$ & $\begin{array}{l}- \\
-\end{array}$ & $\begin{array}{c}-0.003 \\
(-0.666)\end{array}$ \\
\hline $\begin{array}{l}\mathrm{N} \\
\text { Adj. R-squared }\end{array}$ & $\begin{array}{l}294 \\
0.92\end{array}$ & $\begin{array}{l}189 \\
0.92\end{array}$ & $\begin{array}{l}286 \\
0.92\end{array}$ & $\begin{array}{l}270 \\
0.93\end{array}$ & $\begin{array}{l}294 \\
0.92\end{array}$ & $\begin{array}{l}156 \\
0.88\end{array}$ & $\begin{array}{l}249 \\
0.92\end{array}$ \\
\hline
\end{tabular}

Note: Robust t-statistics are shown in brackets. ${ }^{*}$ significant at $10 \%$; ** significant at 5\%.

12 F-Tests were also performed to determine whether cross-section or period dummies were to be included in the different regressions, and the equation estimated accordingly. Dummy variables for membership in the EFTA, EC, and EU were also considered but did not change the results considerably. 
We recognize that not all the countries in our sample were members of the EU at the beginning of the sample period, even though they were part of other free trade arrangements. Estimating the equation for different time periods, to take into account the fact that some of the countries joined later, would have reduced the degrees of freedom considerably. Instead, we tried to capture these effects by using dummy variables for membership, which did not change the results reported here significantly. As we can see from table 3 above, the natural determinants of comparative advantage represented by $h$ p $p$ and Ihuman are significant in most of the regressions with the right sign. Three (lsoc, lhou and lunion) of the six labor standards variables confirm the conventional wisdom that labor standards matter and have a negative effect on export performance while the other three indicators are insignificant. In table 4, we use manufactured exports to EU countries as a percentage of GDP (in logs) as our dependent variable, and the Hausman test favored the random effects model over the fixed effects one. Since our data for exports to EU member countries covers a shorter period, we have fewer observations in these regressions. In this case, Ihuman is significant but not lpop, suggesting possibly that exports are concentrated in manufactured goods that are more capital intensive. Once again, three of the labor standards indicators (lwwell, lsoc, lhou) are significant and the remaining three are not. However, only lhou confirms the conventional wisdom whereas lwell and lsoc point in the opposite direction. 
Table 4: Panel Data Estimates for Equation 2 - Dependent Variable leu

\begin{tabular}{|c|c|c|c|c|c|c|c|}
\hline $\begin{array}{l}\text { Explanatory } \\
\text { Variables }\end{array}$ & (1) & (2) & (3) & (4) & (5) & (6) & (7) \\
\hline Constant & $\begin{array}{l}-13.888^{* *} \\
(-17.515)\end{array}$ & $\begin{array}{c}-11.719 * * \\
(-7.861)\end{array}$ & $\begin{array}{c}-14.766^{* *} \\
(-16.645)\end{array}$ & $\begin{array}{c}-15.712^{* *} \\
(-17.526)\end{array}$ & $\begin{array}{c}-14.723^{* *} \\
(-16.117)\end{array}$ & $\begin{array}{c}-14.092^{* *} \\
(-16.338)\end{array}$ & $\begin{array}{c}-14.320^{* *} \\
(-17.423)\end{array}$ \\
\hline Ipop & $\begin{array}{c}-0.059 \\
(-0.374)\end{array}$ & $\begin{array}{c}0.114 \\
(1.041)\end{array}$ & $\begin{array}{l}-0.011 \\
(-0.067)\end{array}$ & $\begin{array}{c}-0.103 \\
(-0.729)\end{array}$ & $\begin{array}{l}-0.005 \\
(-0.035)\end{array}$ & $\begin{array}{c}-0.127 \\
(-0.921)\end{array}$ & $\begin{array}{c}0.005 \\
(0.032)\end{array}$ \\
\hline lhuman & $\begin{array}{l}2.305^{* *} \\
(10.024)\end{array}$ & $\begin{array}{l}1.356^{* *} \\
(2.761)\end{array}$ & $\begin{array}{c}2.132^{* *} \\
(9.630)\end{array}$ & $\begin{array}{l}2.295^{* *} \\
(8.229)\end{array}$ & $\begin{array}{l}2.353^{* *} \\
(10.717)\end{array}$ & $\begin{array}{l}2.513^{* *} \\
(8.439)\end{array}$ & $\begin{array}{l}2.436^{* *} \\
(10.115)\end{array}$ \\
\hline lwell & $\begin{array}{l}- \\
-\end{array}$ & $\begin{array}{c}1.289 * * \\
(2.719)\end{array}$ & $\begin{array}{l}- \\
-\end{array}$ & - & $\begin{array}{l}- \\
-\end{array}$ & $\begin{array}{l}- \\
-\end{array}$ & - \\
\hline lsoc & $\begin{array}{l}- \\
-\end{array}$ & - & $\begin{array}{c}0.338^{* *} \\
(3.291)\end{array}$ & - & $\begin{array}{l}- \\
-\end{array}$ & - & $\begin{array}{l}- \\
-\end{array}$ \\
\hline lhou & $\begin{array}{l}- \\
-\end{array}$ & $\begin{array}{l}- \\
-\end{array}$ & $\begin{array}{l}- \\
-\end{array}$ & $\begin{array}{c}0.563 * * \\
(3.241)\end{array}$ & $\begin{array}{l}- \\
-\end{array}$ & $\begin{array}{l}- \\
-\end{array}$ & - \\
\hline lunion & - & - & - & - & $\begin{array}{c}0.139 \\
(1.334)\end{array}$ & - & $\begin{array}{l}- \\
-\end{array}$ \\
\hline linj & $\begin{array}{l}- \\
-\end{array}$ & $\begin{array}{l}- \\
-\end{array}$ & $\begin{array}{l}- \\
-\end{array}$ & $\begin{array}{l}- \\
-\end{array}$ & $\begin{array}{l}- \\
-\end{array}$ & $\begin{array}{c}0.005 \\
(0.147)\end{array}$ & $\begin{array}{l}- \\
-\end{array}$ \\
\hline lstr & - & $\begin{array}{l}- \\
-\end{array}$ & $\begin{array}{l}- \\
-\end{array}$ & - & $\begin{array}{l}- \\
-\end{array}$ & $\begin{array}{l}- \\
-\end{array}$ & $\begin{array}{c}-0.013 \\
(-0.887)\end{array}$ \\
\hline $\begin{array}{l}\mathrm{N} \\
\text { Adj. R-squared }\end{array}$ & $\begin{array}{l}175 \\
0.44\end{array}$ & $\begin{array}{l}117 \\
0.50\end{array}$ & $\begin{array}{l}175 \\
0.47\end{array}$ & $\begin{array}{l}151 \\
0.50\end{array}$ & $\begin{array}{l}175 \\
0.44\end{array}$ & $\begin{array}{l}101 \\
0.71\end{array}$ & $\begin{array}{l}152 \\
0.50\end{array}$ \\
\hline
\end{tabular}

Note: Robust t-statistics are shown in brackets. ${ }^{*}$ significant at $10 \%$; ${ }^{* *}$ significant at $5 \%$.

Finally, table 5 above shows the results when the dependent variable, llabint, refers to labor intensive commodities as a percentage of GDP. In this case, the Hausman test favored a random effects model. The human capital variable is significant with the right sign in most regressions but the proxy for the labor/land ratio is not. As for the labor standard variables, Isoc and lunion are positive and significant, indicating that higher standards are in fact related to an improvement in exports of labor intensive goods, which is contrary to the 
conventional wisdom. We also estimated equations with capital intensive manufactures as a percentage of GDP as our dependent variable (results not shown here). Not surprisingly, the human capital variable is highly significant (with t-statistics greater than 10 in most cases) while the proxy for the labor/land ratio is less significant than in table 5 above. Two of the labor standards (lsoc and lwell) were in disagreement with the conventional wisdom while lhou and lstr confirmed it.

Table 5: Panel Data Estimates for Equation 2 - Dependent Variable llabint

\begin{tabular}{|c|c|c|c|c|c|c|c|}
\hline $\begin{array}{l}\text { Explanatory } \\
\text { Variables }\end{array}$ & (1) & (2) & (3) & (4) & (5) & (6) & (7) \\
\hline Constant & $\begin{array}{c}-11.678^{* *} \\
(-13.315)\end{array}$ & $\begin{array}{c}-11.177 * * \\
(-6.482)\end{array}$ & $\begin{array}{c}-12.491 * * \\
(-13.032)\end{array}$ & $\begin{array}{c}-12.497 * * \\
(-11.632)\end{array}$ & $\begin{array}{c}-13.549 * * \\
(-13.849)\end{array}$ & $\begin{array}{c}-13.237 * * \\
(-11.979)\end{array}$ & $\begin{array}{c}-13.071 * * \\
(-13.980)\end{array}$ \\
\hline$\not p o p$ & $\begin{array}{l}-0.307^{*} \\
(-1.830)\end{array}$ & $\begin{array}{c}-0.180 \\
(-1.379)\end{array}$ & $\begin{array}{c}-0.266 \\
(-1.631)\end{array}$ & $\begin{array}{l}-0.320^{*} \\
(-1.890)\end{array}$ & $\begin{array}{c}-0.174 \\
(-1.230)\end{array}$ & $\begin{array}{c}-0.297 \\
(-1.284)\end{array}$ & $\begin{array}{c}-0.228 \\
(-1.271)\end{array}$ \\
\hline Ihuman & $\begin{array}{c}1.189 * * \\
(4.556)\end{array}$ & $\begin{array}{c}0.819 \\
(1.444)\end{array}$ & $\begin{array}{l}1.028 * * \\
(3.999)\end{array}$ & $\begin{array}{l}1.174 * * \\
(3.626)\end{array}$ & $\begin{array}{l}1.263^{* *} \\
(5.101)\end{array}$ & $\begin{array}{l}1.822^{* *} \\
(5.371)\end{array}$ & $\begin{array}{c}1.636^{* *} \\
(6.000)\end{array}$ \\
\hline lowell & $\begin{array}{l}- \\
-\end{array}$ & $\begin{array}{c}0.462 \\
(0.823)\end{array}$ & - & - & - & - & - \\
\hline lsoc & $\begin{array}{l}- \\
-\end{array}$ & - & $\begin{array}{c}0.318^{* *} \\
(2.742)\end{array}$ & $\begin{array}{l}- \\
-\end{array}$ & $\begin{array}{l}- \\
-\end{array}$ & - & - \\
\hline Ihou & $\begin{array}{l}- \\
-\end{array}$ & - & $\begin{array}{l}- \\
-\end{array}$ & $\begin{array}{c}0.249 \\
(1.175)\end{array}$ & $\begin{array}{l}- \\
-\end{array}$ & $\begin{array}{l}- \\
-\end{array}$ & $\begin{array}{l}- \\
-\end{array}$ \\
\hline Iunion & - & - & $\begin{array}{l}- \\
-\end{array}$ & $\begin{array}{l}- \\
-\end{array}$ & $\begin{array}{c}0.316^{* *} \\
(2.737)\end{array}$ & $\begin{array}{l}- \\
-\end{array}$ & $\begin{array}{l}- \\
-\end{array}$ \\
\hline linj & $\begin{array}{l}- \\
-\end{array}$ & $\begin{array}{l}- \\
-\end{array}$ & $\begin{array}{l}- \\
-\end{array}$ & $\begin{array}{l}- \\
-\end{array}$ & - & $\begin{array}{l}-0.005 \\
(-0.114)\end{array}$ & $\begin{array}{l}- \\
-\end{array}$ \\
\hline lstr & $\begin{array}{l}- \\
-\end{array}$ & - & $\begin{array}{l}- \\
-\end{array}$ & $\begin{array}{l}- \\
-\end{array}$ & - & $\begin{array}{l}- \\
-\end{array}$ & $\begin{array}{c}0.017 \\
(1.105)\end{array}$ \\
\hline $\begin{array}{l}\mathrm{N} \\
\text { Adj. R-squared }\end{array}$ & $\begin{array}{l}175 \\
0.17\end{array}$ & $\begin{array}{l}117 \\
0.13\end{array}$ & $\begin{array}{l}175 \\
0.20\end{array}$ & $\begin{array}{l}151 \\
0.26\end{array}$ & $\begin{array}{l}175 \\
0.23\end{array}$ & $\begin{array}{l}101 \\
0.46\end{array}$ & $\begin{array}{l}152 \\
0.21\end{array}$ \\
\hline
\end{tabular}

Note: Robust t-statistics are shown in brackets. ${ }^{*}$ significant at $10 \% ;{ }^{* *}$ significant at $5 \%$. 
Overall, therefore, we obtain very mixed evidence regarding the conventional wisdom, but the fact remains that trade (export) performance is still primarily determined by relative factor endowments and not labor standards. Our results therefore confirm those of Rodrik (1996) and Dehejia and Samy (2004), who used cross-sectional data for large samples consisting of both developed and developing countries. Since our primary interest was to consider the individual effects of standards, Tables 3-5 report results when one labor standard is introduced at a time. Considering all the indicators together reduces the degrees of freedom considerably, and one has to be mindful of multicollinearity among the standards. We have nonetheless tried this and it turns out that the results are not significantly altered when different combinations of standards are introduced ${ }^{13}$. Export performance continues to be determined by the natural determinants of comparative advantage, and we obtain mixed evidence regarding the conventional wisdom. As a further robustness check, we considered shorter time periods for our pooled data (and certain specific years at regular intervals pooled together); again, the overall results did not change significantly, even though we had fewer degrees of freedom.

\subsection{Race to the Bottom?}

Whether one looks at trade or foreign direct investment flows, it is quite obvious that the EU has been characterized by increased integration over the past two decades. This section addresses the issue that increased economic integration will restrict the ability of national governments to set independent policy choices, in our case, the choice over labor standards. The extreme version of this thesis, which we have alluded to in the introduction, is that governments will be forced into a "race to the bottom" in order to remain competitive. Following the seminal work of Viner (1950), it is now widely agreed that the

13 This is also carried out in Rodrik (1996) and Dehejia and Samy (2004) for example. 
overall effects of removing trade barriers on welfare depends on the magnitudes of trade creation and diversion. The empirical literature which has tried to quantify these welfare effects has in general shown that trade creation dominates, in the case of the EU, such that welfare effects are positive overall (Lloyd 1992). It can thus be expected that trade creation will improve working conditions as there is likely to be a positive relationship between working conditions and the level of economic development in the long run, since higher labor standards are presumably a "normal" good demand for which will rise with income. Thus, to the extent that economic integration raises welfare, labor standards will improve over time. Further, even if some standards are low in a given country, this may not improve its competitiveness if other standards are higher; in other words, differences in labor standards across a given country may persist.

Even though integration is more likely to improve labor standards and welfare for participating members, the following possible costs of integration need to be taken into account. Neoclassical trade theory predicts that in the absence of redistributive mechanisms, the benefits of trade liberalization are likely to be shared unevenly among individuals. Specifically, the celebrated Stolper-Samuelson theorem predicts that for economies with an abundant supply of skilled labor, integration may lead to a fall in wages and, by extension, working conditions of the unskilled, to the extent that degraded standards substitute for lower wages in a world of nominal wage stickiness (OECD 1994). The free movement of capital flows in the form of foreign direct investment (FDI) may also exert some pressures on labor standards. If investment indeed flows to countries with relatively lower labor standards, this may create downward pressures on labor standards in other members of the EU, and hence lead to "social dumping". To the extent that workers will migrate to high standard countries in order to take advantage of better social protection, this could lead to 
smaller benefits in countries where social protection is generous. Furthermore, the use of a common currency (the EURO) by most EU members and the resulting loss of monetary policy as a policy instrument to offset macroeconomic shocks, may mean more swings in the business cycle, and hence an increase in social insurance and labor market regulation. Finally, in order to belong to the EMU, countries must maintain low and stable debts, which may lead them to cut social expenditure. In sum, for all the reasons mentioned above, although economic integration may be expected to improve labor standards overall, the possibility of social dumping because of stronger international competition needs to be taken into account, and there is, in principle, ambiguity on the predicted sign and magnitude of the effect.

We therefore consider the evolution of labor standards in the EU over the years 1980-2001, which includes the Single European Act of 1985, the Social Charter of 1989, and the Maastricht Treaty of 1992, all of which led to important reductions in restrictions. Following Barro and Sala-i-Martin (1995) and Sala-i-Martin (1996), the empirical growth literature distinguishes between two types of convergence: " $\sigma$-convergence" and " $\beta$ convergence". When the dispersion of a variable across a control group falls over time, there is said to be $\sigma$-convergence; on the other hand, $\beta$-convergence refers to a situation in which the partial correlation between a given variable over time and its initial level is negative. ${ }^{14}$ In this paper we explore whether or not $\sigma$-convergence in labor standards is occurring across EU member countries, as this is the germane definition for our purposes.

A cursory look at the data reveals a rather mixed picture. Table 5 below reports changes in (proxies for) labor standards over the past two decades. As can be seen, there have been considerable improvements in labor standards represented by the index of labor 
market well-being, total social spending, old age benefits, and safety at the workplace (occupational injuries). However, there have been declines in trade union density over the whole period and an increase in hours worked in the 1990s (even if not in all countries). Overall, the results are not as grim as the conventional wisdom would have it; even though integration may impose constraints on domestic policy, they are evidently not as severe as the pessimists would have predicted.

Table 5: Evolution of Labor Standards in the EU

\begin{tabular}{lcc}
\hline \hline Labor Standard Variable & $\begin{array}{c}\text { Change from } \\
\mathbf{1 9 8 0 ~ t o ~ 1 9 8 9 ~ ( \% ) ~}\end{array}$ & $\begin{array}{c}\text { Change from } \\
\mathbf{1 9 9 0} \text { to 2001 (\%) }\end{array}$ \\
\hline \hline Index of Labor Market Well-Being & $9.5037(7+, 2-)$ & $11.4016(9+, 0-)$ \\
Social Spending (\% of GDP) & & \\
a) Total & $7.6561(12+, 2-)$ & $2.5721(10+, 5-)$ \\
b) Old Age Benefits & $8.9279(10+, 4-)$ & $11.4035(12+, 3-)$ \\
c) Unemployment Benefits & $32.3270(11+, 3-)$ & $-21.0929(4+, 11-)$ \\
& & \\
Hours Worked & $-2.0664(6+, 7-)$ & $4.7749(6+, 7-)$ \\
a) Actual Hours Worked in Manufacturing & $-1.8546(7+, 7-)$ & $6.0105(10+, 5-)$ \\
b) Index of Hours Worked & $-10.7896(3+, 12-)$ & $-10.9958(3+, 12-)$ \\
Trade Union Density & $-28.3019(2+, 5-)$ & $-26.0736(0+, 9-)$ \\
Occupational Injuries & $-40.7985(2+, 11-)$ & $1.5523(2+, 11-)$ \\
Strikes and Lockouts & &
\end{tabular}

Source: authors' calculations based on available data for EU-15. The data is averaged over the relevant period before calculating percentage changes. The numbers in parenthesis refer to the number of countries in the sample that experienced increases $(+)$ or decreases $(-)$ in the relevant variable.

\footnotetext{
14 This is more commonly known as conditional $\beta$-convergence.
} 
Table 6: Sigma-Convergence/Divergence

\begin{tabular}{|c|c|c|c|}
\hline Labor Standard & 1980 & 1990 & 2000 \\
\hline \multicolumn{4}{|c|}{ Index of Labor Market Well-Being } \\
\hline Mean & 0.5019 & 0.5537 & 0.6096 \\
\hline Standard Deviation & 0.0728 & 0.0585 & 0.0536 \\
\hline Coefficient of Variation & 0.1451 & 0.1056 & 0.0879 \\
\hline \multicolumn{4}{|l|}{ Social Spending (\% of GDP) } \\
\hline Mean & 20.6106 & 23.3725 & 23.6935 \\
\hline Standard Deviation & 5.6030 & 4.5044 & 4.2015 \\
\hline Coefficient of Variation & 0.2718 & 0.1927 & 0.1773 \\
\hline \multicolumn{4}{|l|}{ b) Old Age Benefits } \\
\hline Mean & 6.5312 & 7.8746 & 8.6483 \\
\hline Standard Deviation & 1.7955 & 1.9328 & 2.3665 \\
\hline Coefficient of Variation & 0.2749 & 0.2448 & 0.2736 \\
\hline \multicolumn{4}{|l|}{ c) Unemployment Benefits } \\
\hline Mean 1 r & 1.1754 & 1.5023 & 1.2235 \\
\hline Standard Deviation & 1.3380 & 1.1283 & 0.7667 \\
\hline Coefficient of Variation & 1.1383 & 0.7510 & 0.6267 \\
\hline \multicolumn{4}{|c|}{ Hours Worked } \\
\hline \multicolumn{4}{|c|}{ a) Actual Hours Worked in Manufacturing } \\
\hline Mean & 37.6974 & 36.5589 & 37.9393 \\
\hline Standard Deviation & 3.9430 & 5.1400 & 3.3434 \\
\hline Coefficient of Variation & 0.1046 & 0.1406 & 0.0881 \\
\hline \multicolumn{4}{|l|}{ b) Index of Hours Worked } \\
\hline Mean & 95.9443 & 95.5805 & 101.3254 \\
\hline Standard Deviation & 9.2503 & 10.6056 & 1.2315 \\
\hline Coefficient of Variation & 0.0964 & 0.1110 & 0.0122 \\
\hline \multicolumn{4}{|l|}{ Trade Union Density } \\
\hline Mean & 49.3067 & 43.0467 & 38.8733 \\
\hline Standard Deviation & 19.9344 & 21.3973 & 22.5345 \\
\hline Coefficient of Variation & 0.4043 & 0.4971 & 0.5882 \\
\hline \multicolumn{4}{|l|}{ Occupational Injuries } \\
\hline Mean & 7.9500 & 4.6571 & 4.1250 \\
\hline Standard Deviation & 4.4396 & 4.0644 & 2.8519 \\
\hline Coefficient of Variation & 0.5584 & 0.8727 & 0.6914 \\
\hline \multicolumn{4}{|l|}{ Strikes and Lockouts } \\
\hline Mean & 572.2308 & 307.2308 & 399.8182 \\
\hline Standard Deviation & 723.1404 & 480.8370 & 812.8068 \\
\hline Coefficient of Variation & 1.2637 & 1.5651 & 2.0329 \\
\hline
\end{tabular}

Source: authors' calculations based on available data for EU-15 
Table 6 above reports means and standard deviations for the labor standards variables for 1980, 1990 and 2000. In the case of the index of labor market well being, social spending (and its sub-categories), occupational injuries, the means have increased and there are smaller variations around them. For trade union density and strikes and lockouts, the means have gone down, but the variations around the means have increased. Hours worked have remained fairly stable. Based on standard deviations, we have evidence of both $\sigma$ convergence and $\sigma$-divergence. The problem, however, with the previous interpretation, is that it ignores changes in the means of the distributions, which is obvious from the numbers reported in Table 5. As a result, we report coefficients of variation and interpret a fall in this variable as further evidence of $\sigma$-convergence. Once again, the evidence is mixed as we observe convergence in the index of labor market well-being, social spending (and its subcategories) and hours worked, and divergence for the others.

\section{Conclusion}

This paper has examined the effects of labor standards on export performance of countries that are part of the European Union by employing panel data over the period 1980 to 2001. In so doing, we have tried to test the conventional wisdom that countries with lower labor standards will experience an improvement in export competitiveness. Our empirical estimates indicate some evidence in favor of the conventional wisdom, although overall labor standards appear to exert less of an influence on export performance than the traditional determinants of comparative advantage predicted by neoclassical trade theory. This is. in our view. a significant contribution to both the literature on economic integration in the EU, and on the competitive effects of labor standards in general, as the majority of empirical studies, cited in the introduction, use cross-sectional data and are perforce unable 
to exploit movements in labor standards over time. Our study thus represents a substantial methodological improvement. We have also examined the issue of convergence of standards across countries to try to shed some light on the race to the bottom argument. Our results point towards convergence in some standards and divergence in others, suggesting that on this important question, the jury is still very much out.

In the European context, in recent years, there has been much discussion and a number of studies delving into the social consequences of EU enlargement, a natural question as the ten new members are at fairly different (and generally lower) levels of economic development compared to the EU-15 countries. It would be interesting to examine current and historical labor regulations in these countries, as well as trade flows to ascertain the veracity of the arguments linking trade and labor standards, as well as the race to the bottom hypothesis. There is, regrettably, as yet insufficient data to explore these hypotheses, given the very recent accession of the ten new members. Based on the results in this paper, however, we can conjecture that trade flows will continue to be determined mostly by the natural determinants of comparative advantage, and, looking at the current political economy, that countries will choose their own social policies (including labor standards) based mostly on domestic considerations. Formal tests of these conjectures await the advent of new data of sufficient quality and quantity.

In the context of the empirical trade literature, it would also be interesting to see how, if at all, our results change when testing alternative trade models, such as the gravity model, with the different indicators of labor standards used in this paper, as well as disaggregated trade data for manufactured goods that takes into account skill intensity. Furthermore, a systematic evaluation of $\beta$-convergence for standards would also allow us to 
check whether the race to the bottom holds when other factors that affect standards are taken into account. All of these questions remain the subject of future research. 


\section{Bibliography}

Alam, A. (1992) "Labor Standards and Comparative Advantage". Unpublished Doctoral Dissertation, Columbia University.

Barro, R.J., and Sala-i-Martin, X. (1995) Economic Growth. MIT Press, Cambridge.

Bassanini, A., and Scarpetta, S. (2001) "Does Human Capital Matter for Growth in OECD Countries? Evidence from Pooled Mean-Group Estimates," Economics Department Working Papers No. 282, OECD.

Bhagwati J. and Ramaswami V.K. (1963) "Domestic Distortions, Tariffs and the Theory of Optimum Subsidy," Journal of Political Economy 71(1), 44-50.

Brecher, R.A. (1974a) “Optimal Commercial Policy for a Minimum-Wage Economy," Journal of International Economics, 4, 139-49.

Brecher, R.A. (1974b) "Minimum Wage Rates and the Pure Theory of International Trade," Quarterly Journal of Economics, 88, 98-116.

Brown, D.K., Deardoff, A.V. and Stern, R.M. (1996) "International Labor Standards and Trade: A Theoretical Analysis". In Bhagwati, J.N. and Hudec, R.E. (eds) Fair Trade and Harmonization: Prerequisites for Free Trade? Volume 1, Economic Analysis. Cambridge and London: MIT Press.

Dehejia, V.H. (1998) “Can Standards Immiserize?”. Economics Letters, 59, 361-66.

Dehejia, V.H. and Garbo, L. (1994) "Standards Harmonization, Comparative Advantage and Growth: The General Equilibrium Implications of Ross Perot”. Unpublished Paper, Columbia University.

Dehejia, V., and Samy, Y. (2004) "Trade and Labor Standards: Theory and New Empirical Evidence," Journal of International Trade and Economic Development, 13(2), 177-96, June.

Engerman, S. (2003) "The History and Political Economy of International Labor Standards." In Basu, K., Horn, H., Roman, L., and Shapiro, J. (eds) International Labor Standards: History, Theories, and Policy Options, Blackwell Publishers: Oxford.

Flanagan, R. J. (2002) "Labor Standards and International Competitive Advantage". bttp:// wmw.iza.org/iza/en/papers/transatlantic/1_flanagan.pdf

Gitterman, D. P. (2003) "European Integration and Labour Market Cooperation: A Comparative Regional Perspective," Journal of European Social Policy, 13(2), 99-120.

ILO (2004) A Fair Globalization: Creating Opportunities for All, Report of the World Commission on the Social Dimension of Globalization, Geneva. 
Johnson, H.G. (1965) "Optimum Intervention in the Presence of Domestic Distortions." In Caves R.E., Kenen P.B. and Johnson H.G. (eds) Trade, Growth and the Balance of Payments: Essays in Honour of Gottfried Haberler. Amsterdam: North-Holland.

Lloyd, P. (1992) "Regionalisation and World Trade," OECD Economic Studies, 18, Spring.

Mah, J.S. (1997) "Core Labor Standards and Export Performance in Developing Countries". The World Economy, 20(6), 773-785.

Krueger, A.B. (2000) "From Bismarck to Maastricht: The March to European Union and the Labour Compact". NBER Working Paper No. 7456, January.

OECD (1994) "Labor Standards and Economic Integration." In OECD Employment Outlook 1994. (Paris, France: Organization for Economic Cooperation and Development).

OECD (1996) Trade, Employment and Labor Standards (Paris, France: Organization for Economic Cooperation and Development).

OECD (2002) International Trade and Core Labor Standards (Paris, France: Organization for Economic Cooperation and Development).

Rodrik, D. (1996) "Labour Standards in International Trade: Do they matter and what do we do about them?". In Lawrence, Robert Z., Rodrik, Dani. and Whalley, John. (eds) Emerging agenda for global trade: High stakes for developing countries. Overseas Development Council Essay No. 20, Washington D.C: Johns Hopkins University Press.

Sala-i-Martin, X. (1996) "Regional Cohesion: Evidence and Theories of Regional Growth and Convergence." European Economic Review, 40, 1325-1352.

Samy, Y., and Rodriguez G. (2003) "Analyzing the Effects of Labor Standards on U.S. Export Performance. A Time Series Approach with Structural Change," Applied Economics, 35, 1043-1051, June.

Van Beers, C. (1998) "Labour Standards and Trade Flows of OECD Countries," The World Economy, 21(1), 57-73.

Viner, Jacob (1950) “The Customs Union Issue.” Carnegie Endowment for International Peace, New York.

Srinivasan, T.N. (1996) "International Trade and Labour Standards from an Economic Perspective," in Challenges to the New World Trade Organisation, edited by P. van Dijck and G. Faher, Kluwer Law International, The Hague. 
Appendix A

Migration Rates to EU (1992-2001)

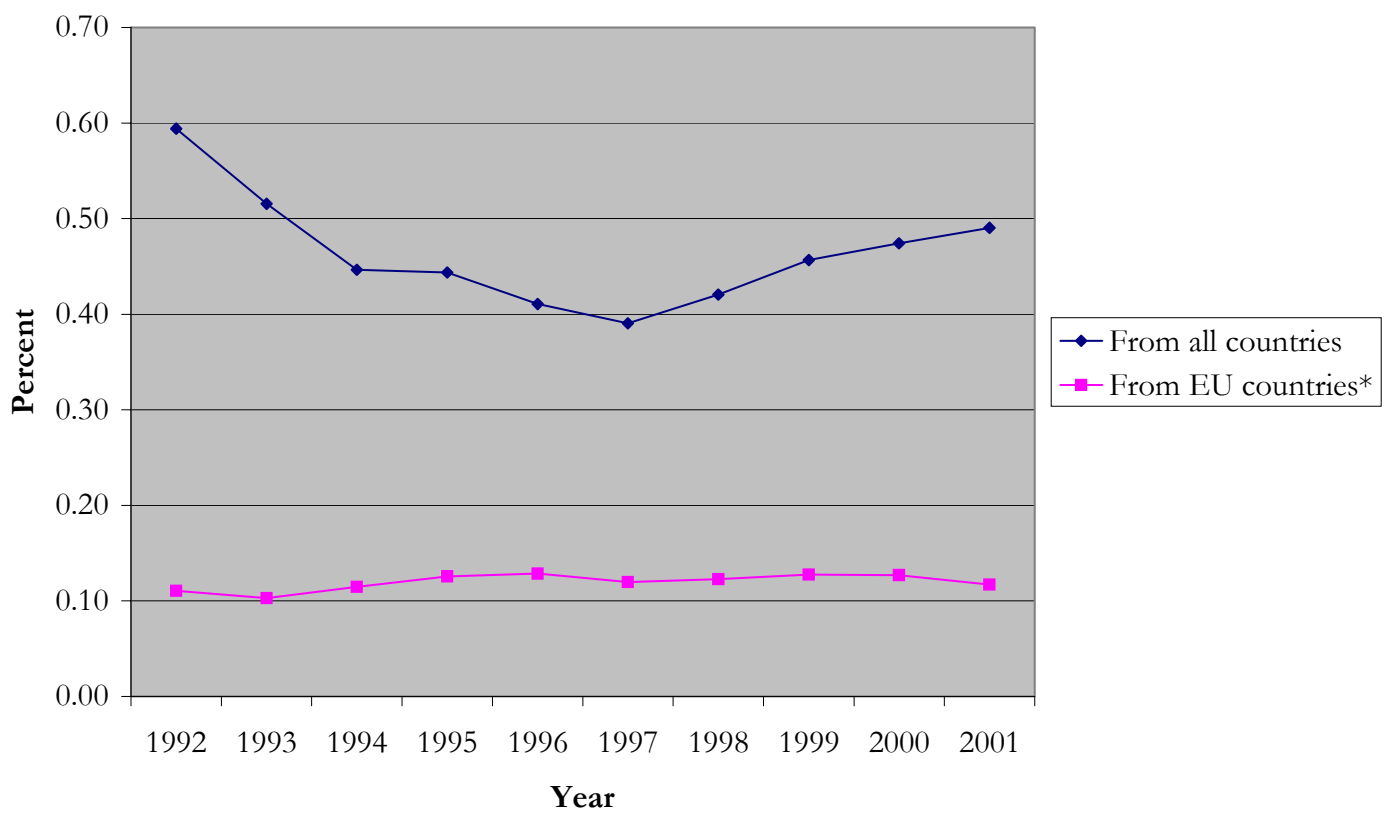

Source: Authors' calculations based on OECD Data

* excluding Austria, Finland, Greece, Italy and Spain 


\section{CESifo Working Paper Series}

(for full list see www.cesifo-group.de)

1681 Wladimir Raymond, Pierre Mohnen, Franz Palm and Sybrand Schim van der Loeff, Persistence of Innovation in Dutch Manufacturing: Is it Spurious?, March 2006

1682 Andrea Colciago, V. Anton Muscatelli, Tiziano Ropele and Patrizio Tirelli, The Role of Fiscal Policy in a Monetary Union: Are National Automatic Stabilizers Effective?, March 2006

1683 Mario Jametti and Thomas von Ungern-Sternberg, Risk Selection in Natural Disaster Insurance - the Case of France, March 2006

1684 Ken Sennewald and Klaus Waelde, “Itô’s Lemma“ and the Bellman Equation for Poisson Processes: An Applied View, March 2006

1685 Ernesto Reuben and Frans van Winden, Negative Reciprocity and the Interaction of Emotions and Fairness Norms, March 2006

1686 Françoise Forges, The Ex Ante Incentive Compatible Core in Exchange Economies with and without Indivisibilities, March 2006

1687 Assar Lindbeck, Mårten Palme and Mats Persson, Job Security and Work Absence: Evidence from a Natural Experiment, March 2006

1688 Sebastian Buhai and Coen Teulings, Tenure Profiles and Efficient Separation in a Stochastic Productivity Model, March 2006

1689 Gebhard Kirchgaessner and Silika Prohl, Sustainability of Swiss Fiscal Policy, March 2006

1690 A. Lans Bovenberg and Peter Birch Sørensen, Optimal Taxation and Social Insurance in a Lifetime Perspective, March 2006

1691 Moritz Schularick and Thomas M. Steger, Does Financial Integration Spur Economic Growth? New Evidence from the First Era of Financial Globalization, March 2006

1692 Burkhard Heer and Alfred Maussner, Business Cycle Dynamics of a New Keynesian Overlapping Generations Model with Progressive Income Taxation, March 2006

1693 Jarko Fidrmuc and Iikka Korhonen, Meta-Analysis of the Business Cycle Correlation between the Euro Area and the CEECs, March 2006

1694 Steffen Henzel and Timo Wollmershaeuser, The New Keynesian Phillips Curve and the Role of Expectations: Evidence from the Ifo World Economic Survey, March 2006

1695 Yin-Wong Cheung, An Empirical Model of Daily Highs and Lows, March 2006 
1696 Scott Alan Carson, African-American and White Living Standards in the $19^{\text {th }}$ Century American South: A Biological Comparison, March 2006

1697 Helge Berger, Optimal Central Bank Design: Benchmarks for the ECB, March 2006

1698 Vjollca Sadiraj, Jan Tuinstra and Frans van Winden, On the Size of the Winning Set in the Presence of Interest Groups, April 2006

1699 Martin Gassebner, Michael Lamla and Jan-Egbert Sturm, Economic, Demographic and Political Determinants of Pollution Reassessed: A Sensitivity Analysis, April 2006

1700 Louis N. Christofides and Amy Chen Peng, Major Provisions of Labour Contracts and their Theoretical Coherence, April 2006

1701 Christian Groth, Karl-Josef Koch and Thomas M. Steger, Rethinking the Concept of Long-Run Economic Growth, April 2006

1702 Dirk Schindler and Guttorm Schjelderup, Company Tax Reform in Europe and its Effect on Collusive Behavior, April 2006

1703 Françoise Forges and Enrico Minelli, Afriat's Theorem for General Budget Sets, April 2006

1704 M. Hashem Pesaran, Ron P. Smith, Takashi Yamagata and Liudmyla Hvozdyk, Pairwise Tests of Purchasing Power Parity Using Aggregate and Disaggregate Price Measures, April 2006

1705 Piero Gottardi and Felix Kubler, Social Security and Risk Sharing, April 2006

1706 Giacomo Corneo and Christina M. Fong, What's the Monetary Value of Distributive Justice?, April 2006

1707 Andreas Knabe, Ronnie Schoeb and Joachim Weimann, Marginal Employment Subsidization: A New Concept and a Reappraisal, April 2006

1708 Hans-Werner Sinn, The Pathological Export Boom and the Bazaar Effect - How to Solve the German Puzzle, April 2006

1709 Helge Berger and Stephan Danninger, The Employment Effects of Labor and Product Markets Deregulation and their Implications for Structural Reform, May 2006

1710 Michael Ehrmann and Marcel Fratzscher, Global Financial Transmission of Monetary Policy Shocks, May 2006

1711 Carsten Eckel and Hartmut Egger, Wage Bargaining and Multinational Firms in General Equilibrium, May 2006

1712 Mathias Hoffmann, Proprietary Income, Entrepreneurial Risk, and the Predictability of U.S. Stock Returns, May 2006 
1713 Marc-Andreas Muendler and Sascha O. Becker, Margins of Multinational Labor Substitution, May 2006

1714 Surajeet Chakravarty and W. Bentley MacLeod, Construction Contracts (or "How to Get the Right Building at the Right Price?”), May 2006

1715 David Encaoua and Yassine Lefouili, Choosing Intellectual Protection: Imitation, Patent Strength and Licensing, May 2006

1716 Chris van Klaveren, Bernard van Praag and Henriette Maassen van den Brink, Empirical Estimation Results of a Collective Household Time Allocation Model, May 2006

1717 Paul De Grauwe and Agnieszka Markiewicz, Learning to Forecast the Exchange Rate: Two Competing Approaches, May 2006

1718 Sijbren Cnossen, Tobacco Taxation in the European Union, May 2006

1719 Marcel Gérard and Fernando Ruiz, Interjurisdictional Competition for Higher Education and Firms, May 2006

1720 Ronald McKinnon and Gunther Schnabl, China's Exchange Rate and International Adjustment in Wages, Prices, and Interest Rates: Japan Déjà Vu?, May 2006

1721 Paolo M. Panteghini, The Capital Structure of Multinational Companies under Tax Competition, May 2006

1722 Johannes Becker, Clemens Fuest and Thomas Hemmelgarn, Corporate Tax Reform and Foreign Direct Investment in Germany - Evidence from Firm-Level Data, May 2006

1723 Christian Kleiber, Martin Sexauer and Klaus Waelde, Bequests, Taxation and the Distribution of Wealth in a General Equilibrium Model, May 2006

1724 Axel Dreher and Jan-Egbert Sturm, Do IMF and World Bank Influence Voting in the UN General Assembly?, May 2006

1725 Swapan K. Bhattacharya and Biswa N. Bhattacharyay, Prospects of Regional Cooperation in Trade, Investment and Finance in Asia: An Empirical Analysis on BIMSTEC Countries and Japan, May 2006

1726 Philippe Choné and Laurent Linnemer, Assessing Horizontal Mergers under Uncertain Efficiency Gains, May 2006

1727 Daniel Houser and Thomas Stratmann, Selling Favors in the Lab: Experiments on Campaign Finance Reform, May 2006

1728 E. Maarten Bosker, Steven Brakman, Harry Garretsen and Marc Schramm, A Century of Shocks: The Evolution of the German City Size Distribution 1925 - 1999, May 2006

1729 Clive Bell and Hans Gersbach, Growth and Enduring Epidemic Diseases, May 2006 
1730 W. Bentley MacLeod, Reputations, Relationships and the Enforcement of Incomplete Contracts, May 2006

1731 Jan K. Brueckner and Ricardo Flores-Fillol, Airline Schedule Competition: ProductQuality Choice in a Duopoly Model, May 2006

1732 Kerstin Bernoth and Guntram B. Wolff, Fool the Markets? Creative Accounting, Fiscal Transparency and Sovereign Risk Premia, May 2006

1733 Emmanuelle Auriol and Pierre M. Picard, Government Outsourcing: Public Contracting with Private Monopoly, May 2006

1734 Guglielmo Maria Caporale and Luis A. Gil-Alana, Modelling Structural Breaks in the US, UK and Japanese Unemployment Rates, May 2006

1735 Emily J. Blanchard, Reevaluating the Role of Trade Agreements: Does Investment Globalization Make the WTO Obsolete?, May 2006

1736 Per Engström and Bertil Holmlund, Tax Evasion and Self-Employment in a High-Tax Country: Evidence from Sweden, May 2006

1737 Erkki Koskela and Mikko Puhakka, Cycles and Indeterminacy in Overlapping Generations Economies with Stone-Geary Preferences, May 2006

1738 Saku Aura and Thomas Davidoff, Supply Constraints and Housing Prices, May 2006

1739 Balázs Égert and Ronald MacDonald, Monetary Transmission Mechanism in Transition Economies: Surveying the Surveyable, June 2006

1740 Ben J. Heijdra and Ward E. Romp, Ageing and Growth in the Small Open Economy, June 2006

1741 Robert Fenge and Volker Meier, Subsidies for Wages and Infrastructure: How to Restrain Undesired Immigration, June 2006

1742 Robert S. Chirinko and Debdulal Mallick, The Elasticity of Derived Demand, Factor Substitution and Product Demand: Corrections to Hicks' Formula and Marshall's Four Rules, June 2006

1743 Harry P. Bowen, Haris Munandar and Jean-Marie Viaene, Evidence and Implications of Zipf's Law for Integrated Economies, June 2006

1744 Markku Lanne and Helmut Luetkepohl, Identifying Monetary Policy Shocks via Changes in Volatility, June 2006

1745 Timo Trimborn, Karl-Josef Koch and Thomas M. Steger, Multi-Dimensional Transitional Dynamics: A Simple Numberical Procedure, June 2006

1746 Vivek H. Dehejia and Yiagadeesen Samy, Labor Standards and Economic Integration in the European Union: An Empirical Analysis, June 2006 